\title{
IMPLEMENTASI METODE DISKUSI DALAM MENINGKATKAN KEMAMPUAN BERPIKIR KREATIF PADA HASIL BELAJAR IPS SISWA KELAS IV
}

\author{
Ismuhul Fadhil \\ Universitas Islam Negeri Sunan Kalijaga, Yogyakarta \\ Email: Email: ismuhulfadhilazzam@gmail.com
}

Submit: 14 April 2020, Revisi: 7 Juni 2020, Approve: 12 November 2020

\begin{abstract}
This study aims to see the application of the discussion method in improving creative thinking skills in social studies learning outcomes of grade IV students. The research method used was classroom action research which consisted of two cycles. Each cycle consists of stages of planning, implementing, observing and reflecting. The first cycle of teacher activities obtained a score of $3.27 \%$, student activity was $2.69 \%$, the learning outcomes in the first cycle showed that 18 students had completed and 22 other students had not. The results in cycle II experienced an increase, teacher activity obtained a score of $3.94 \%$ and was included in the good category, student activity obtained 3.69\% which was included in the good category, while the overall completeness of student learning outcomes was 33 students complete, and 7 other students had not. reach completeness. It can be seen that in cycle II student learning outcomes increased compared to cycle I.
\end{abstract}

Keywords: Discussion Method, Creative Thinking, IPS Learning

Pengutipan: Ismuhul Fadhil. (2020). Implementasi Metode Diskusi dalam Meningkatkan Kemampuan Berpikir Kreatif pada Hasil Belajar IPS Siswa Kelas IV. JMIE: Journal of Madrasah Ibtidaiyah Education, 4(2), 2020, 197-205. jmie.v4i2.165.

Permalink/DOI: http://dx.doi.org/10.32934/jmie.v4i2.165 


\section{PENDAHULUAN}

Pendidikan adalah suatu proses dalam rangka mempengaruhi siswa supaya memiliki kemampuan, baik kemampuan berpikir, berbuat, dan kemampuan memecahkan masalah dalam kehidupan sehari-hari. Seiring perkembangan zaman, pendidikan di Indonesia diharapkan dapat menghasilkan berbagai macam kualitas, pendidikan yang berkualitas bukan hanya siswa yang memiliki kemampuan intelektual, melainkan siswa yang mampu mengembangkan potensinya. Berkembang potensi siswa diantaranya adalah menjadikan mereka lebih kreatif, baik kreatif dalam melakukan suatu hal maupun kreatif dalam berpikir. Mewujudkan siswa yang kreatif dibutuhkan cara atau metode dalam pembelajaran yang mampu meningkatkan partisipasi keaktifan siswa dalam proses belajar mengajar. Banyak metode pembelajaran yang dapat digunakan, salah satunya metode diskusi terbimbing dapat menjadi pilihan dalam pembelajaran yang mengajak siswa untuk belajar secara aktif, meningkatkan berpikir kreatif, sehingga menjaga perhatian siswa tetap tertuju pada proses pembelajaran agar dapat mencapai hasil yang diharapkan.

Pelaksanaan proses pembelajaran dengan menggunakan metode dapat membuat siswa lebih mudah dalam memecahkan masalah yang ada, siswa bukan hanya mampu menghafal materi pelajaran melainkan juga dapat memahami konsep pembelajaran tersebut yang lebih aktif dan kreatif dengan menggunakan suatu metode (Gunawan, 2013). Peraturan Kementerian Pendidikan dan Kebudayaan Nomor 24 Tahun 2016 pasal 2 ayat 4, menjelaskan bahwa kompetensi yang terdapat dalam Kurikulum 2013 berisi tentang kemampuan dan materi suatu mata pelajaran pada lembaga yang mengacu pada kompetensi inti, hal ini berkaitan dengan pasal 2 ayat 1 yang mana menjelaskan bahwa kompetensi inti dalam Kurikulum 2013 merupakan tingkatan kemampuan aktif, kreatif, inovatif dan berpikir tingkat tinggi yang harus dimiliki siswa untuk mencapai standar kompetensi lulusan setiap kelas (Kemendikbud, 2016).

Ilmu pengetahuan sosial merupakan salah satu mata pelajaran yang diajarkan pada siwa tingkat dasar yang berisi tentang materi ilmu sosial dan lingkungan. Meningkatkan daya berpikir aktif, kreatif, dan menarik pada siswa dalam pembelajaran IPS kiranya diperlukan metode pembelajaran yang bervariasi dan relevan, salah satunya metode diskusi. Penggunaan metode diskusi yang akan memperoleh pemahaman yang mendalam dari kejadian-kejadian yang lebih luas dan dapat membuat kreativitas berpikir pada siswa. Ilmu pengetahuan sosial yang mengkaji berbagai kegiatan dasar manusia secara sosial dan ilmiah yang dikemas dalam rangka memberikan wawasan serta pemahaman pada siswa secara mendalam, kususnya di tingkat dasar (Ahmad Susanto, 2017).

Ilmu pengetahuan sosial secara umum memiliki peranan penting dalam membentuk warga Negara yang baik kususnya siswa, siswa dalam hal ini dapat mengembangkan tanggung jawab sebagai anggota masyarakat, menanamkan nilai-nilai musyawarah dan mampu bersikap 
demokrasi. Pengembangan metode diskusi pada pembelajaran ilmu pengetahuan sosial sangat diperlukan untuk melatih siswa agar dapat mampu aktif dan berpikir kreatif. Sejak usia dasar, siswa harus dikembangkan kemampuan berpikir kreatif melalui pendidikan formal, agar siswa lebih terarah dan dapat meningkatkan kualitas sumber daya manusia yang berhubungan dengan pendidikan di Indonesia (Annisa Defara, Arita Marini, 2019).

Proses belajar mengajar siswa sangat diharapkan aktif dan kreatif, baik aktif dalam menjawab pertanyaan, aktif bertanya, aktif dalam mengerjakan tugas, aktif dalam berdiskusi yang kususnya untuk mengacu penguasaan mata pelajaran. Proses pembelajaran ilmu pengetahuan sosial, keaktifan dan kekreatifan siswa sangat rendah dari siswa yang bersemangat dan aktif, sebagian besar enggan bertanya serta berdiskusi tentang permasalahan yang sedang dibahas, siswa juga kurang bisa mengembangkan pemikirannya dalam proses belajar mengajar yang sedang berlangsung serta tidak bisa mengembangkan ketika guru memberikan suatu contoh permasalahan. Apabila siswa kurang didorong untuk mengembangkan keaktifan dan kemampuan diri sendiri, maka hal itu dapat menimbulkan hambatan dari hasil belajar. Seluruh potensi yang dimiliki siswa, perlu untuk didorong, dilatih, diasah, sehingga akan berkembang secara optimal dan dapat memperoleh hasil belajar yang sesuai dengan KKM (Kriteria Ketuntasan Maksimal).

Munculnya masalah di atas, peneliti dapat mengidentifikasi penyebab terjadinya siswa kurang aktif, tidak semangat, tidak memiliki kekreatifan dalam berpikir, dikarenakan tidak adanya metode sebagai cara yang relevan untuk digunakan dalam proses belajar mengajar, sehingga tidak ada daya tarik bagi siswa untuk berkonsentrasi pada pelajaran dan materi yang disampaikan. Penggunaan metode yang tepat dalam proses mengajar sangat diperlukan oleh setiap guru, dalam hal ini guru hanya menggunakan metode ceramah saja, ketika mengajar guru kurang komunikatif untuk meningkatkan keaktifan siswa, serta lingkungan belajar kurang kondusif dan kurang tertata rapi, sehingga siswa kurang termotivasi untuk aktif, berpikir kreatif, serta kurang bersamangat.

Berdasarkan uraian di atas, peneliti berusaha mencari solusi yang tepat untuk meningkatkan kreativitas, minat dan daya tarik pada siswa, akhirnya ditemukan alternative pemecahan masalah dengan menggunakan metode diskusi dalam proses belajar mengajar, untuk meningkatkan kemampuan berpikir kreatif pada hasil belajar IPS kelas IV yang kreatif dalam berpikir serta aktif dalam suasana.

\section{METODE PENELITIAN}

Penelitian ini menggunakan penelitian tindakan kelas. Penelitian ini merupakan teknik agar pembelajaran yang dikelola oleh guru mengalami peningkatan secara terus menerus melalui setiap perbaikan (Miaz, 2014). Penelitian tindakan kelas ini dilakukan terdiri dari dua siklus, setiap siklusnya terdiri dari tahapan perencanaan, pelaksanaan, pengamatan dan refleksi 
(Arikunto, 2010). Penelitian ini dilakukan di MIN 3 Aceh Besar kelas IV dengan jumlah 30 siswa. Teknik pengumpulan data yang digunakan adalah observasi dan tes. Adapun analisis data pada penelitian ini bersumber dari aktivitas guru, aktivitas siswa, dan hasil belajar.

\section{HASIL DAN PEMBAHASAN}

\section{Metode Diskusi}

Metode merupakan sebuah cara, susunan, teknik, atau alat pengukur dalam sebuah bidang ilmiah. Metode juga digunakan sebagai perangkat pedoman atau kegiatan terstruktur untuk membantu menghasilkan pembelajaran yang relevan, meningkat, dan berkembang (Riedl et al., 2014). Metode diskusi bertujuan untuk mengemukakan gagasan, ide, dan masalah. Gagasan, ide, dan masalah dicari penyelesaian serta pemecahannya secara bersama-sama oleh siswa dengan bertujuan untuk menambah pengetahuan, menjawab pertanyaan serta untuk membuat sebuah keputusan dalam pembelajaran (Mitasari \& Prasetiyo, 2016).

Proses belajar mengajar guru sangat dituntut untuk menggunakan metode dan media di saat pembelajaran berlangsung. Proses belajar mengajar guru dihadapkan untuk memilih metode-metode dari sekian banyak metode yang telah ditemui oleh para ahli sebelumya. Metode diskusi ialah interaksi antara siswa dan guru atau siswa dengan siswa untuk memecahkan masalah dalam proses pembelajaran, menganalisis materi, menggali dan mencari tau lebih dalam tentang materi yang diajarkan pada saat proses pembelajaran (Lamajau, 2014).

Metode diskusi merupakan sebuah cara yang digunakan dalam proses pembelajaran guna untuk mencapai hasil belajar siswa, metode diskusi juga sebagai percakapan ilmiah yang berisikan pertukaran pendapat yang dijalankan dengan pertanyaan, pemunculan ide atau pendapat yang dilakukan lebih dari satu orang, metode ini lebih diarahkan bagi siswa dalam memecahankan masalah untuk memperoleh kebenaran. Metode diskusi ini dilakukan untuk memberdayakan siswa dalam mengasah kemampuan berdiskusi, mengasah berkomunikasi, mengasah keberanian dalam menyampaikan, baik dengan sesama siswa maupun dengan guru (Ulfa, 2012).

Penggunaan metode diskusi dalam proses belajar mengajar antara lain ialah : (1) melatih siswa untuk bertanya, berkomunikasi, berdiskusi, menafsirkan serta menyimpulkan suatu materi pembelajaran, (2) melatih untuk membentuk kestabilan sosial-emosianal anak, (3) meningkatkan kemampuan berpikir kreatif siswa untuk memecahkan masalah, (4) mengembangkan keberhasilan siswa untuk membuat dan menemukan pendapat, (5) melatih siswa untuk berani berkomunikasi dan mengemukakan suatu masalah dalam pembelajaran (Suharjo, 2010). 


\section{Berpikir Kreatif}

Berpikir dapat diartikan sebagai keterampilan kognitif untuk memperoleh pengetahuan. Adapun keterampilan berpikir dalam ranah kognitif terdiri dari beberapa tingkatan, yaitu : 1) Pengetahuan. 2) Pemahaman. 3) Penerapan. 4) Analisis. 5) Evaluasi. 6) Menciptakan (Tikkanen \& Aksela, 2012). Berpikir kreatif adalah suatu proses pemikiran yang dapat menghasilkan berbagai ide dan jawaban. Berpikir kreatif munculnya ditandai dengan adanya ide-ide baru yang digunakan oleh individu untuk menghasilkan sebuah proses berpikir (Sekar et al., 2015). Berpikir kreatif suatu proses dan produk yang dimiliki oleh setiap manusia agar dapat memperoleh informasi dari manapun dan mampu memproses menjadi sebuah pengetahuan dengan cara berpikir (Saddhono et al., 2019).

Berpikir kreatif juga suatu tuntutan untuk dapat menciptakan sebuah ide, gagasan, temuan-temuan atau alternatif solusi dalam upaya menyelesaikan permasalah yang terjadi dalam proses pembelajaran. Kemampuan berpikir kreatif siswa pada pembelajaran ilmu pengetahuan sosial dapat dikatakan sebagai upaya untuk menemukan solusi dalam penyelesaian masalah yang terkait dengan ilmu pengetahuan sosial, dengan adanya penyelesaian dengan materi yang diberikan, dapat dikatakan sebagai ukuran keberhasilan belajar siswa (Faelasofi, 2017).

Kemampuan berpikir pada siswa merupakan tahapan untuk melatih pengetahuan kognitif, yaitu: siswa mampu menganalisis, mengevaluasi, dan memberikan penilaian terhadap suatu fakta yang dipelajari dan bisa menggabungkan fakta dan ide, sehingga mampu menciptakan sesuatu yang baru berdasarkan apa yang sudah dipelajari (Annuuru et al., 2017). Berpikir kreatif juga dapat membuat siswa memiliki keterampilan, kemampuan menganalisis serta mampu berpikir tingkat tinggi (Handayani et al., 2019). Berpikir kreatif dapat diartikan sebagai kemampuan penyelesaian suatu masalah, manfaatnya dapat melatih siswa untuk berpikir lancar, luwes, dapat melakukan elaborasi dan memiliki daya cipta (Marliani, 2015).

Berdasarkan pada prosesnya, berpikir kreatif disebut sebagai berpikir kompleks. Berpikir kompleks merupakan berpikir tingkat tinggi yang mencakup pemecahan masalah, dapat mengambil keputusan, berpikir kritis dan tentunya berpikir kreatif (Ode et al., 2016). Kemampuan berpikir kreatif siswa pada level yang lebih tinggi, bertujuan untuk menerima berbagai informasi, memecahkan suatu masalah, menguraikan materi pembelajaran, membuat kesimpulan serta dapat mengambil keputusan tertentu (Rina Rahmi, Iin Nurhalizha, 2020). Contoh berpikir kreatif dengan menggunakan metode diskusi. Guru memberikan sebuah topik materi tentang nama-nama negara pada pembelajaran ilmu pengetahuan sosial disertai dengan bimbingannya, siswa langsung berpikir tentang ibu kota negara, berdiskusi dengan siswa lainnya tentang kehebatan dari sebuah negara tersebut, dapat menyebut lagu kebangsaannya, dan tentunya dapat mengalir temuan-temuan baru dengan saling berdiskusi sesama siswa, 
menjabarkan lebih lanjut serta menunjukkan ide-ide lain berkaitan dengan topik materi yang diberikan guru.

\section{Hasil Penelitian}

Bedasarkan hasil penelitian yang menggunakan metode diskusi untuk meningkatkan hasil belajar siswa. Pra siklus presentase aktivitas belajar siswa 51\% dan masuk kriteria cukup aktif. Siklus I terjadi peningkatan sebesar 22,2\% dari 51\% menjadi 73,2\% masuk kedalam kriteria aktif. Siklus ke II terjadi peningkatan yang signifikan sebesar 10,4\% dari 73,2\% menjadi 83,6\% dan masuk kriteria sangat aktif. Penerapan metode diskusi untuk meningkatkan hasil belajar siswa pada pembelajaran PKN ini sangatlah mengalami peningkatan dari hasil yang telah dicapai (Sari et al., 2014).

\section{Pengamatan Siklus 1}

Hasil pengamatan siklus I pada aktivitas guru, aktivitas siswa dan hasil belajar. Aktivitas guru yang diperoleh selama proses belajar mengajar IPS dengan menggunakan metode diskusi mendapat nilai 3,27\% yang termasuk dalam kategori cukup. Hasil observasi aktivitas siswa dalam kegiatan belajar pada siklus 1 mendapat nilai 2,69\% dan termasuk kategori cukup. Hasil belajar menunjukkan jumlah siswa yang mencapai ketuntasan belajar sebanyak 18 siswa, sedangkan 22 siswa lainnya belum mencapai ketuntasan belajar secara keseluruhan.

Keterangan.

$$
\begin{aligned}
& 1,00 \leq \mathrm{TKS}<1,50 \text { (tidak baik) } \\
& 1,50 \leq \mathrm{TKS}<2,50 \text { (kurang baik) } \\
& 2,50 \leq \mathrm{TKS}<3,50 \text { (cukup) } \\
& 3,50 \leq \mathrm{TKS}<4,50 \text { (baik) } \\
& 4,50 \leq \mathrm{TKS}<5,00 \text { (sangat baik) }
\end{aligned}
$$

Refleksi pada siklus I, aktivitas guru dalam proses belajar mengajar menunjukkan hasil yang mendekati maksimal. Guru masih memiliki kekurangan dalam memotivasi, menerapkan metode, dan mengelola proses belajar mengajar, dengan demikian pengelolaan pembelajaran aktivitas guru perlu ditingkatkan pada siklus ke II. Aktivitas siswa pada siklus I juga masih memiliki kekurangan, hal ini disebabkan siswa belum terbiasa dengan pembelajaran yang menerapkan metode diskusi. Oleh karena itu guru harus memberikan motivasi dan pemahaman yang lebih efektif pada siswa di siklus ke II. Bedasarkan hasil belajar pada siklus I banyak siswa yang belum mencapai ketuntasan belajar, oleh karena itu peneliti harus melakukan tindak lanjut pada penelitian selanjutnya di siklus ke II. 


\section{Pengamatan Siklus II}

Hasil pengamatan aktivitas guru di siklus II dengan menggunakan metode diskusi terbimbing dalam proses belajar mengajar IPS mendapat nilai 3,94\% termasuk dalam kategori baik. Aktivitas siswa pada siklus II mendapat nilai rata-rata 3,69\% dan termasuk kategori baik. Sedangkan hasil belajar siswa secara keseluruhan lebih meningkat dibandingkan pada siklus I. Siswa dengan ketuntasan belajar sebanyak 33 siswa dan siswa belum mencapai ketuntasan belajar sebanyak 7 siswa.

Keterangan.

$$
\begin{aligned}
& 1,00 \leq \mathrm{TKS}<1,50 \text { (tidak baik) } \\
& 1,50 \leq \mathrm{TKS}<2,50 \text { (kurang baik) } \\
& 2,50 \leq \mathrm{TKS}<3,50 \text { (cukup) } \\
& 3,50 \leq \mathrm{TKS}<4,50 \text { (baik) } \\
& 4,50 \leq \mathrm{TKS}<5,00 \text { (sangat baik) }
\end{aligned}
$$

Refleksi pada siklus II pembelajaran IPS dengan menggunakan metode diskusi dalam meningkatkan berpikir kreatif, guru sudah menunjukkan hasil yang maksimal dengan peningkatan nilai dari siklus I, ini dikarenakan guru sudah mampu mengelola pembelajaran dengan baik. Aktivitas siswa pada siklus ke II lebih meningkat dan maksimal, ini disebabkan siswa sudah mulai memahami metode yang disampaikan guru dikelas. Observasi pada siklus II terhadap hasil belajar siswa secara keseluruhan meningkat dibandingkan dengan siklus I. Jadi dapat disimpulkan bahwa proses belajar mengajar dengan menggunakan metode diskusi pada pembelajaran IPS telah mencapai ketuntasan maksimal dari segi hasil yang dicapai.

\section{SIMPULAN}

Bedasarkan penelitian yang telah dilakukan, dapat disimpulkan bahwa implementasi metode diskusi dalam meningkatkan kemampuan berpikir kreatif pada hasil belajar IPS siswa kelas IV, sangat memuaskan dengan adanya peningkatan. Siklus I aktivitas guru memperoleh $3,27 \%$ dan aktivitas siswa 2,69\%, sedangkan hasil belajar terdapat 22 siswa yang tidak tuntas dan 18 siswa yang tuntas. Hasil memuaskan dapat dilihat pada siklus ke II dengan adanya peningkat, aktivitas guru 3,94\%, aktivitas siswa 3,69\% dan ketuntasan hasil belajar siswa menjadi 33 siswa yang tuntas dan 7 siswa yang tidak tuntas. Peningkatan ini dikarenakan adanya perubahan yang semakin aktif dalam proses belajar dengan mengimplementasikan metode diskusi, lancar dalam berpikir kreatif, aktif menyampaikan, aktif bertanya, aktif berdiskusi, serta siswa dapat menyelesaikan masalah yang terjadi dalam proses belajar mengajar. 


\section{DAFTAR PUSTAKA}

Ahmad Susanto. (2017). Pendidikan IPS: Upaya Mengembangkan Kemampuan Berpikir Kreatif. Prosiding Diskusi Panel Pendidikan "Menjadi Guru Pembelajar,” April, 23-28.

Annisa Defara, Arita Marini, S. K. (2019). Hubungan Antara Gaya Belajar Dengan Kemampuan Berpikir Kreatif Dalam Pembelajaran Ilmu Pengetahuan Sosial Siswa Kelas V Sekolah Dasar. Jurnal Dinamika Sekolah Dasar, vol 1 no 1.

Annuuru, T. A., Johan, R. C., \& Ali, M. (2017). Peningkatan Kemampuan Berpikir Tingkat Tinggi dalam Pelajaran Ilmu Pengetahuan Alam Peserta Didik Sekolah Dasar Melalui Model Pembelajaran Treffinger. Jurnal Edutcehnologia, 3(2), 136-144.

Arikunto. (2010). Suharsimi Arikunto.pdf. In Prosedur Penelitian Suatu Pendekatan Praktik-Revisi ke $X$.

Faelasofi, R. (2017). Identifikasi Kemampuan Berpikir Kreatif Matematika Pokok Bahasan Peluang. JURNAL E-DuMath, 3(2), 155-163. https:/ / doi.org/10.26638/je.460.2064

Gunawan, R. (2013). Implementasi Pengembangan Profesionalisme Bagi Guru. Journal of Socius. .

Handayani, H., Sopandi, W., Syaodih, E., Suhendra, I., \& Hermita, N. (2019). RADEC: An Alternative Learning of Higher Order Thinking Skills (HOTs) Students of Elementary School on Water Cycle. Journal of Physics: Conference Series, 1351(1). https://doi.org/10.1088/1742-6596/1351/1/012074

Kemendikbud. (2016). Permendikbud 24 tahun 2016 tentang Kompetensi Inti dan Kompetensi Dasar Pelajaran pada Kurikulum 2013. Jakarta.

Lamajau, E. (2014). Peningkatan Kemampuan Keterampilan Berbicara Siswa Kelas V SDN Sampaka Kec . Bualemo Kab . Banggai Melalui Metode Diskusi Kelompok. Jurnal Kreatif Tadulako Online, 5(1), 201-211. http://jurnal.untad.ac.id/jurnal/index.php/JKTO/article/view/3770

Marliani, N. (2015). Peningkatan Kemampuan Berpikir Kreatif Matematis Siswa melalui Model Pembelajaran Missouri Mathematics Project (MMP). Formatif: Jurnal Ilmiah Pendidikan MIPA, 5(1), 14-25. https://doi.org/10.30998/formatif.v5i1.166

Miaz, Y. (2014). Penelitian tindakan kelas bagi guru dan dosen. In Penelitian tindakan kelas bagi guru dan dosen.

Mitasari, Z., \& Prasetiyo, N. A. (2016). Penerapan Metode Diskusi-Presentasi Dipadu Analisis Kritis Artikel melalui Lesson Study untuk Meningkatkan Pemahaman Konsep, Kemampuan Berpikir Kritis, dan Komunikasi. Jurnal Bioedukatika, 4(1), 11. https://doi.org/10.26555/bioedukatika.v4i1.4736

Ode, W., Arisanti, L., Sopandi, W., \& Widodo, A. (2016). Analisis Penguasaan Konsep dan 
Keterampilan Berpikir Kreatif Siswa Sd Melalui Project Based Learning. EduHumaniora: Jurnal Pendidikan Dasar, vol 8 no 1(1).

Riedl, R., Davis, F. D., \& Hevner, A. R. (2014). Towards a neuroIS research methodology: Intensifying the discussion on Methods, Tools, And Measurement. Journal of the Association for Information Systems, 15(October 2014), 1-35. https://doi.org/10.17705/1jais.00377

Rina Rahmi, Iin Nurhalizha, N. N. (2020). Relevance of Bahasa Indonesia Main Materials With Hots ( Higher Order Thinking Skills ). Al-Bidayah: Jurnal Pendidikan Dasar Islam, $X I I(1)$.

Saddhono, K., Hasanudin, C., \& Fitrianingsih, A. (2019). The ability to think creatively on SSCs using schoology apps, how is the student's language metacognitive awareness? Ingenierie Des Systemes d'Information, 24(4), 367-375. https://doi.org/10.18280/isi.240402

Sari, T. I., Mardiati, Y., \& Khutobah. (2014). Penerapan Metode Diskusi dengan Menggunakan Media Gambar Untuk Meningkatkan Aktivitas dan Hasil Belajar Siswa kelas III dalam Pembelajaran Pkn Tema Lingkungan di SDN Sumberlesung 02 Ledokombo Jember ( The Application of Learning Discussion Method by Using. Edukasi Unej, I(2), 36-39.

Sekar, D. K. S., Pudjawan, K., \& Margunayasa, I. G. (2015). Pembelajaran Ipa Pada Siswa Kelas Iv Universitas Pendidikan Ganesha. E-Journal PGSD Universitas Pendidikan Ganesha Jurusan PGSD, 3(1), 11.

Suharjo. (2010). Pengarub metode diskusi dan pemberian tugas ditinjau dari motivasi berprestasi dan kreativitas siswa terhadap prestasi belajar siswa.

Tikkanen, G., \& Aksela, M. (2012). Analysis of Finnish chemistry Matriculation Examination questions according to Cognitive Complexity. Nordic Studies in Science Education, 8(3), 257-268. https://doi.org/10.5617/nordina.532.

Ulfa, M. (2012). Optimalisasi Hasil Belajar Ipa Tentang Sistem Gerak Pada Manusia Melalui Metode Diskusi Dengan Tehnik Pembelajaran Tutor Sebaya. Jurnal Dinamika, Vol 3 No 1. 